\title{
Phenotypic plasticity of habitat use by three temperate eel species, Anguilla anguilla, $A$. japonica and $A$. rostrata
}

\author{
Françoise Daverat ${ }^{1, *}$, Karin E. Limburg ${ }^{2}$, Isabel Thibault ${ }^{3}$, Jen-Chieh Shiao ${ }^{4}$, \\ Julian J. Dodson ${ }^{3}$, François Caron ${ }^{6}$, Wann-Nian Tzeng ${ }^{7}$, Yoshiyuki Iizuka ${ }^{5}$, \\ Håkan Wickström ${ }^{8}$
}

\author{
${ }^{1}$ Cemagref, 50 Avenue de Verdun, 33612 Cestas, France \\ ${ }^{2}$ SUNY College of Environmental Science \& Forestry, Syracuse, New York 13210, USA \\ ${ }^{3}$ Département de Biologie, Université Laval, Ste-Foy, Québec G1K 7P4, Canada
}

${ }^{4}$ Institute of Cellular and Organismic Biology, and ${ }^{5}$ Institute of Earth Sciences, Academia Sinica, 128, Section 2, Academia Road, Nankang, Taipei, Taiwan 115, ROC

${ }^{6}$ Ministère des Ressources Naturelles et de la Faune du Québec, 675, boul. René-Lévesque Est, Québec (Québec) G1R 5V7, Canada

${ }^{7}$ Institute of Fisheries Science, College of Life Science, National Taiwan University, Taipei, Taiwan 106, ROC ${ }^{8}$ Swedish Board of Fisheries, Institute of Freshwater Research, 178 93, Drottningholm, Sweden

\begin{abstract}
Habitat use patterns of 3 species of temperate eels, Anguilla anguilla, A. japonica and A. rostrata, were investigated using otolith strontium:calcium ratio life history transects. Published and unpublished data from 6 sites (Canada, United States, Sweden, France, Taiwan and Japan) sampled across the geographical range of each eel species were compiled. Sr:Ca patterns indicated that the 3 species displayed similar patterns of habitat use. In all sites, patterns of habitat use consisted of either residency in one habitat (fresh, brackish, or marine) or movements between habitats. One movement pattern consisted of either a single change or 2 changes of habitat from fresh to brackish waters, or from brackish water to freshwater. Seasonal movements between fresh and brackish waters were observed for all 3 species. When only a single habitat switch event was detected, it occurred between 3 and 5 yr of age. Occurrence of eels with no freshwater experience was demonstrated, but such eels accounted for a smaller proportion of the overall sample than eels with some (even brief) freshwater experience. Contrary to the common convention that these are obligate catadromous species, we must now consider them as facultative catadromous, with far more flexibility in habitat use. The most variable parameter among study sites was the relative proportion, rather than the diversity, of lifetime spent in the various habitat use patterns. Eels found at higher latitudes exhibited a greater probability of remaining in the lower reaches of watersheds in brackish water. Diversity of habitat use appears to be a common strategy of temperate eel species, and, as a life history tactic, is under environmental control.
\end{abstract}

KEY WORDS: Habitat use · Anguilla spp · Otolith Sr:Ca

Resale or republication not permitted without written consent of the publisher

\section{INTRODUCTION}

Anguillid eel species display a remarkable similarity in their life history traits. Anguillidae all spawn in deep oceanic waters. Anguillid larvae, the leaf-like leptocephali, are advected by oceanic currents to continen- tal shelves. The migration distance between spawning grounds and nursery areas varies with species, the European eel Anguilla anguilla undertaking the longest distance of migration $(\sim 6000 \mathrm{~km})$. This species spawns in the Sargasso Sea and drifts with the Gulf Stream and North Atlantic Current to the continental 
shelf of Europe and North Africa. The American eel A. rostrata also spawns in the Sargasso Sea and travels 2000 to $3000 \mathrm{~km}$ into North American waters while the Japanese eel A. japonica spawning area is located west of the Mariana Islands (NW Pacific) and its nursery grounds extend through continental waters of East Asia. Tropical species have shorter migrations (Marui et al. 2001). Leptocephalus larvae metamorphose into glass eels as they arrive at continental shelves (Bertin 1951, Tesch 2003). Glass eels become pigmented elvers as they penetrate estuaries, rivers and streams and complete their growth phase in a large choice of habitats (lagoons, estuaries, marshes, rivers, lakes and streams). The growth phase typically lasts from 3 to $15 \mathrm{yr}$ and is followed by a second metamorphosis into silver eel, a pre-pubertal stage. Silver eels achieve their sexual maturation as they swim back to their spawning grounds (Van den Thillart et al. 2004).

Although the presence of yellow eels (juveniles) in brackish and marine waters has long been known, the dominating paradigm has been that eel growth phase was restricted to freshwater (Fontaine 1996). However, growing evidence from otolith microchemistry demonstrates the widespread occurrence of amphidromous and marine individuals that have experienced little or no freshwater (Tzeng et al. 1997, Tsukamoto et al. 1998, Limburg et al. 2003) and a high degree of flexibility in habitat use patterns.

Otolith growth patterns and chemical composition potentially provide detailed individual chronologies of habitat use that are of great value to ecological studies. Early studies on strontium incorporation into eel otoliths of Anguilla japonica showed that strontium:calcium ( $\mathrm{Sr}: \mathrm{Ca})$ ratio levels correlated with the salinity of the water (Tzeng 1996, Kawakami et al. 1998). Strontium is taken up in proportion to ambient concentrations (Bath et al. 2000, Kraus \& Secor 2004) and the effect of a shift in habitat on the Sr:Ca incorporation in the otolith of $A$. anguilla was demonstrated by Daverat et al. (2005). Measurements of Sr:Ca ratios across microstructural features in eel otoliths have been broadly used to infer life history periods spent in fresh, brackish, and marine environments (Bertin 1951, Tzeng et al. 1997, Tsukamoto et al. 1998, Tzeng et al. 2000, Limburg et al. 2003, Tesch 2003). These studies hypothesised the coexistence within eel Anguilla spp. populations of different life history tactics related to the choice of habitat (marine, brackish, freshwater) or a shift of habitat (Tsukamoto \& Arai 2001, Jessop et al. 2002, Tzeng et al. 2002, Morrison et al. 2003, Kotake et al. 2004).

The aim of this comparative study is first to explore the diversity of the different life histories of 3 species of temperate eels (Anguilla anguilla, A. japonica and A. rostrata) using variations in otolith $\mathrm{Sr}$ Ca ratios. Sec- ond, the influence of geographic location and species on the distributions of different eel life histories is investigated. Finally, we discuss the ecological meaning of the different nursery habitat use patterns as established strategies.

\section{MATERIALS AND METHODS}

The present work relies both on published (Tsukamoto \& Arai, 2001, Tzeng et al. 2002, 2003, Limburg et al. 2003, Morrison et al. 2003, Daverat et al. 2005) and unpublished data from I. Thibault, J. J. Dodson, F. Caron, W. N. Tzeng, J. C. Shiao and Y. Iizuka. Data sets were chosen based on sample size, and sampling scale. Data sets dealing with eels which had probably been stocked or with impounded watercourses were discarded from this analysis in order to remove possible bias.

Main study sites. Most sites within the species' ranges (Fig. 1) are watersheds such as the Kaoping River (Taiwan), St. Jean River (Canada), East River (Canada), Hudson River (United States) and Gironde River (France) (Table 1).

Sample collection. Eels were collected by a variety of fishing methods including fixed traps on dams across rivers, electrofishing, fish wheels, eel pots, fyke nets, trawling, and lines as described in each project (Tsukamoto \& Arai 2001, Jessop et al. 2002, Tzeng et al. 2002, Limburg et al. 2003, Morrison et al. 2003, Tzeng et al. 2003, Daverat et al. 2005).

Otolith preparation. For all studies, sagittal otoliths were extracted, cleaned to minimize chemical contamination, and embedded in resin. Otoliths were sectioned either on the sagittal plane or the frontal plane by fine polishing until the core was exposed. The surface of otoliths was smoothed with 1 and $0.5 \mu \mathrm{m}$ diamond paste.

Otolith X-ray microprobe Sr:Ca analysis. Most samples were analysed using similar methodology with small variations as detailed in Tsukamoto \& Arai (2001), Tzeng et al. (2002), Limburg et al. (2003), Morrison et al. (2003), and Daverat et al. (2005). A wavelength dispersive X-ray electron microprobe was used to obtain either maps of $\mathrm{Sr}$ and Ca X-ray intensity on the whole otolith surface, or a transect of measures along an axis from the core of the otolith to the edge (so-called 'life history transect').

Otolith microPIXE Sr:Ca analysis. Some Baltic Sea otoliths were analysed by proton-induced X-ray emission microanalysis ( $\mathrm{PIXE}$ ), a method described in Limburg et al. (2003). A grid of $128 \times 128$ pixels was scanned to map out large areas of the otolith in order to obtain a picture (2-D map) of $\mathrm{Sr}$ :Ca ratios for the whole sample surface. The data sets were then normalised to counts per charge. 


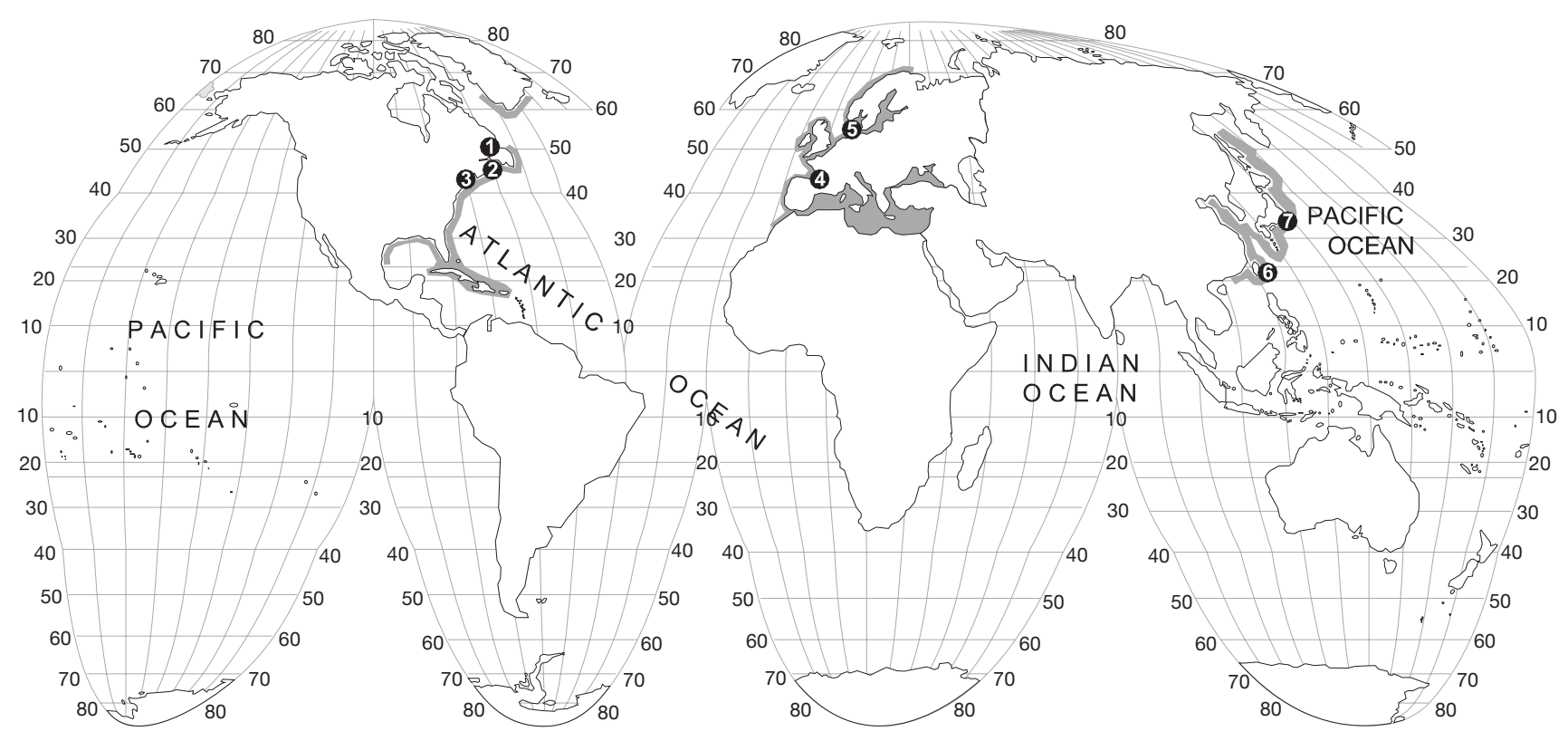

Fig. 1. Anguilla anguilla, A. japonica and A. rostrata. Main study sites showing the geographical range of each species: ( 1) Gaspé Peninsula, Quebec, Canada; (2) Nova Scotia, Canada; (3) Hudson River, United States; (4) Gironde River, France; (5) Baltic Sea exit, Sweden; (6) Kaoping River, Taiwan and (7) Japan

Interpretation of measures of $\mathrm{Sr}$ :Ca ratios. The interpretation of Sr:Ca variations along the otolith radius in terms of habitat use pattern and movements between water masses was based on laboratory and field validations (Daverat et al. 2005). Frequency distributions of Sr:Ca values were compared for fish collected in freshwater, brackish and marine sites to verify that the gradient of $\mathrm{Sr}$ :Ca values was positively correlated with salinity gradient (Tzeng et al. 2002, Limburg et al. 2003, Morrison et al. 2003). Maps of Sr:Ca measures and line transects of $\mathrm{Sr}$ :Ca measures are interpreted as habitat use (freshwater, brackish water or marine water) throughout life, as otoliths grow continually. Only the otolith Sr:Ca ratio measurements starting from the glass eel stage were interpreted.

Data analysis. Logistic regression was applied to the proportion of resident eels in the estuaries (number of residents divided by sample size). SAS software Ver. 8 (2000) was used to analyse the relationship between the proportion of residents in brackish water, and latitude as an explanatory variable. This technique is broadly used in ecology (Collett 1991, Oberdorff et al. 2001). The proportion of residents (presence/absence of residents) response curve describes the probability of residents being

Table 1. Anguilla anguilla, A. japonica and A. rostrata. Relevant characteristics of the major study sites

\begin{tabular}{|c|c|c|c|c|c|}
\hline Ecosystem & Source & Species & $\begin{array}{c}\text { Latitude } \\
\left({ }^{\circ} \mathrm{N}\right)\end{array}$ & $\begin{array}{c}\text { Water } \\
\text { temperature } \\
\text { range }\left({ }^{\circ} \mathrm{C}\right)\end{array}$ & $\begin{array}{c}\text { Salinity } \\
\text { range }\end{array}$ \\
\hline Baltic exit, Sweden and Denmark & Limburg et al. (2003) & A. anguilla & 55 & $2-18$ & $0-25$ \\
\hline Gironde River basin, France & Daverat \& Tomás (2006) & & 44 & $7-24$ & $0-35$ \\
\hline Kaoping River basin, Taiwan & Tzeng et al. (2002) & A. japonica & 22 & $18-30$ & $0-32$ \\
\hline Tone and Fukui river basins, Japan & Tsukamoto \& Arai (2001) & & $30-37$ & $6-23$ & $0-29$ \\
\hline Mikawa Bay (fed by 3 rivers), Japan & Tzeng et al. (2003) & & 34 & $8-28$ & $25-33$ \\
\hline Pearl River, China & & & 23 & & 0 \\
\hline Hudson River basin, United States & Morrison et al. (2003) & A. rostrata & 42 & $0-27$ & $0-24$ \\
\hline East River, Canada & Jessop et al. (2002) & & 45 & $-1-17$ & $0-32$ \\
\hline St. Jean estuary, Canada & I. Thibault et al. (unpubl.) & & 48 & $-0.3-24$ & $1-28$ \\
\hline St. Jean River and Sirois Lake, Canada & & & 48 & $\begin{array}{c}0-24 \\
\text { (covered with } \\
\text { ice in winter) }\end{array}$ & 0 \\
\hline
\end{tabular}


present as a function of an environmental variable (latitude). A Generalised Linear Model (GLM, McCullagh \& Nelder 1989) with a binomial distribution and a logit link function was fitted to the proportion of brackish water residents. A level of $\alpha=0.05$ was selected prior to conducting statistical testing.

\section{RESULTS}

\section{Overall diversity of habitat use}

Life history transects and their interpretation are illustrated for Anguilla rostrata (Fig. 2), A. anguilla (Fig. 3), and A. japonica (Fig. 4). Sr:Ca otolith values measured across site of capture, and species, remained in a narrow range of values. Freshwater Sr:Ca values varied from $1 \times 10^{-3}$ for the Gironde estuary, France $(A$. anguilla, Fig. 3), and up to $3 \times 10^{-3}$ for the Kaoping River, Taiwan (A. japonica, Fig. 4). Sr:Ca values ranged from $2 \times 10^{-3}$ to $8 \times 10^{-3}$ for estuaries whereas marine values were above $6 \times 10^{-3}$.

There is a considerable variety in patterns of habitat use, with more than 6 different patterns identified. The patterns consist of either residency in 1 habitat (fresh/ brackish/marine) from glass eel through silver eel stages (or until collection), or what we term 'nomadic movements' between habitats (Table 2).

The variability of movements is considerable, however, the general suite of movements may be sum-
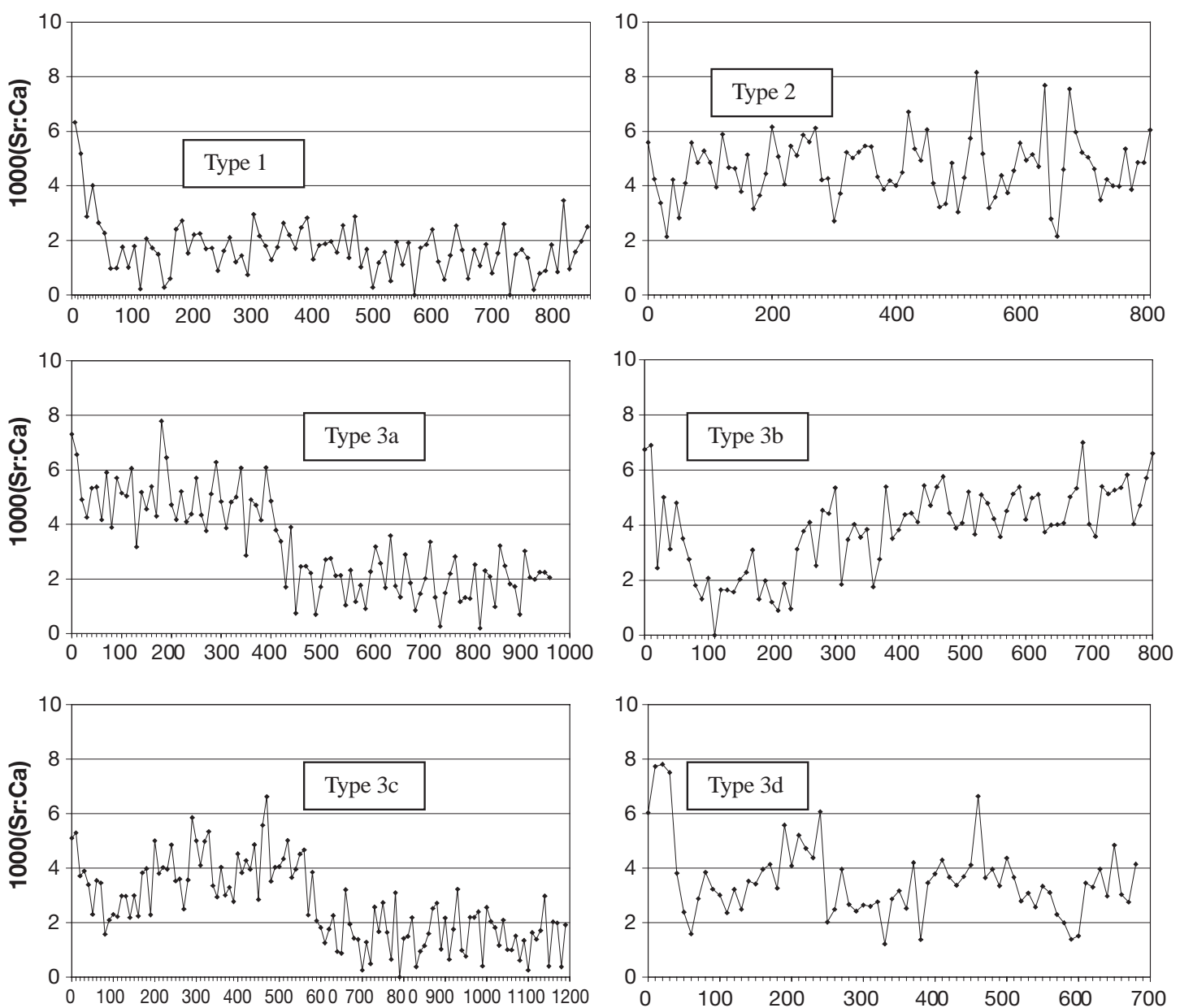

Distance from elver mark to the edge $(\mu \mathrm{m})$

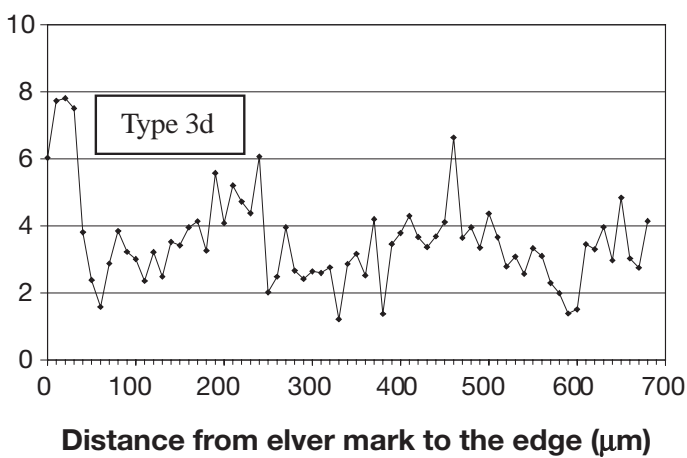

Fig. 2. Anguilla rostrata. Sr: Ca ratio variations along transects from first annulus (elver check) to the otolith edge in American eels representative of the 6 main patterns of habitat use in the St. Jean River, St. Jean estuary and Sirois Lake, Gaspé Peninsula, Canada. Type 1: residence in freshwater; Type 2: residence in brackish habitat; Type 3: nomadic movements, 3a: residence in brackish environment more than 2 yr to freshwater, 3b: residence in freshwater, then movement to brackish habitat, 3c: freshwater residence, movement to estuary then movement to freshwater, $3 \mathrm{~d}$ : other estuarine behavior with no defined pattern (I. Thibault et al. unpubl. data) 
marised as follows: (1) residence in freshwater, followed by a move back to the estuary or the sea, (2) residence in brackish water, followed by residence in freshwater, (3) marine residence, with subsequent movement into brackish water (4) freshwater residence, movement to estuary/sea then movement to freshwater (2 changes of habitat), or (5) seasonal or irregular movements between marine and/or brackish and/or freshwater habitats. To a lesser extent, mixed modes of habitat use patterns were also found.

All patterns of habitat use were observed in the 3 species at nearly all the sites (Table 2). Note that Swedish eels reported in this study (Limburg et al. 2003) are unique in that they are already fingerling yellow eels by the time they recruit to freshwater, with a part of their early life spent crossing the Baltic Sea. As such, their Sr:Ca pattern starts with a brackish or marine episode before recruitment to the estuary.

\section{Schedules of habitat shift}

The age at habitat shift has been estimated by several authors for eels displaying single habitat shifts. Comparisons (Table 3) showed that eels switched habitat within a narrow range of age classes. For most species and sites, habitat switches occurred before age class 5+ with most individuals switching at age class 3+ (Table 3).
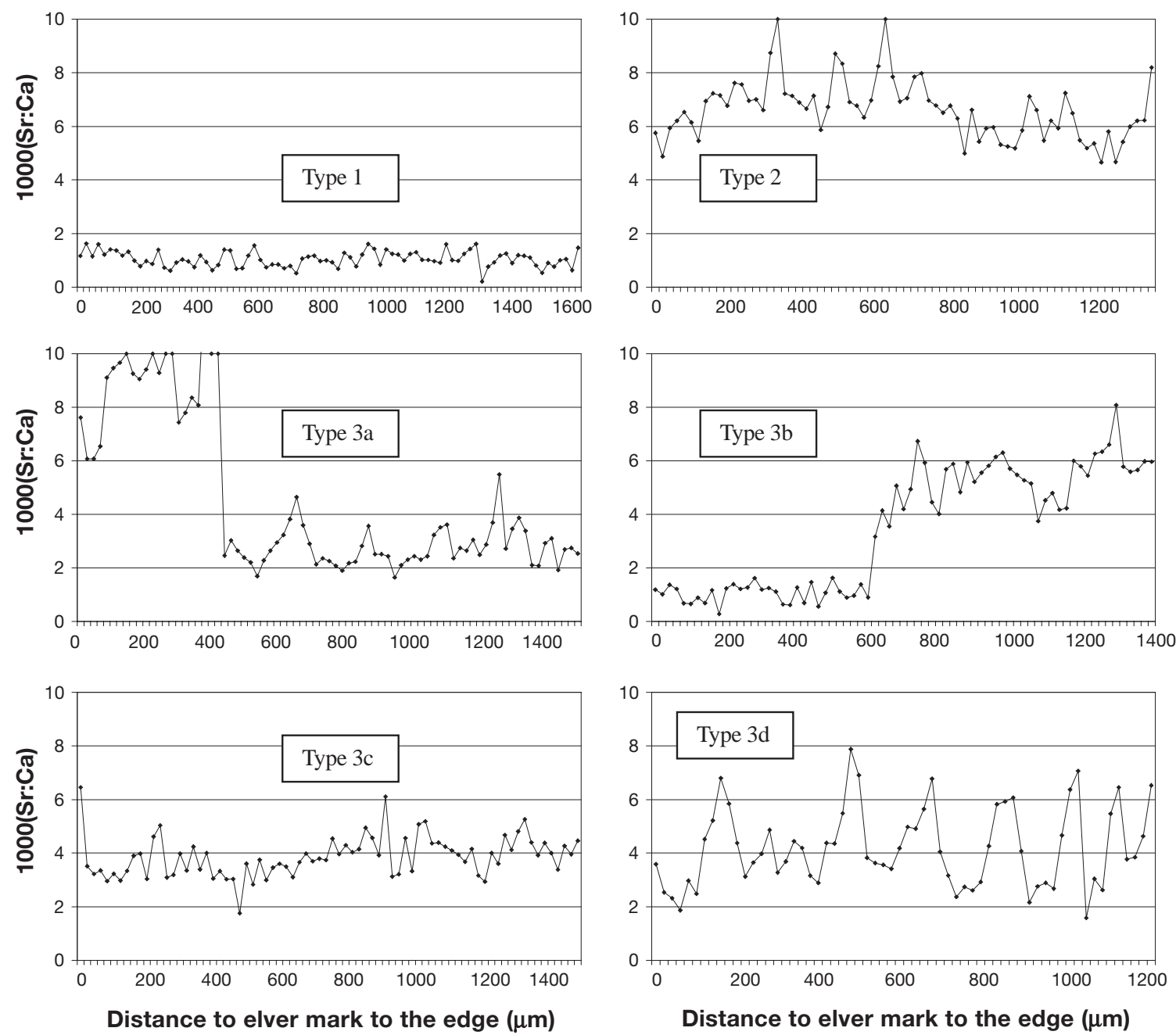

Fig. 3. Anguilla anguilla. Sr:Ca ratio variations along transects from first annulus (elver check or glass eel mark) to the otolith edge in European eels representative of 6 different patterns of habitat use in the Gironde Watershed, SW France. Type 1: residence in freshwater; Type 2: residence in coastal environment; Type 3: residence in the estuary; Type 3a-d: nomadic movements; 3a: residence in marine compartment, movement to the estuary; 3b: Residence in freshwater, movement to the estuary; 3d: Seasonal movements between the lower and upper part of the estuary (Daverat et al. 2005) 

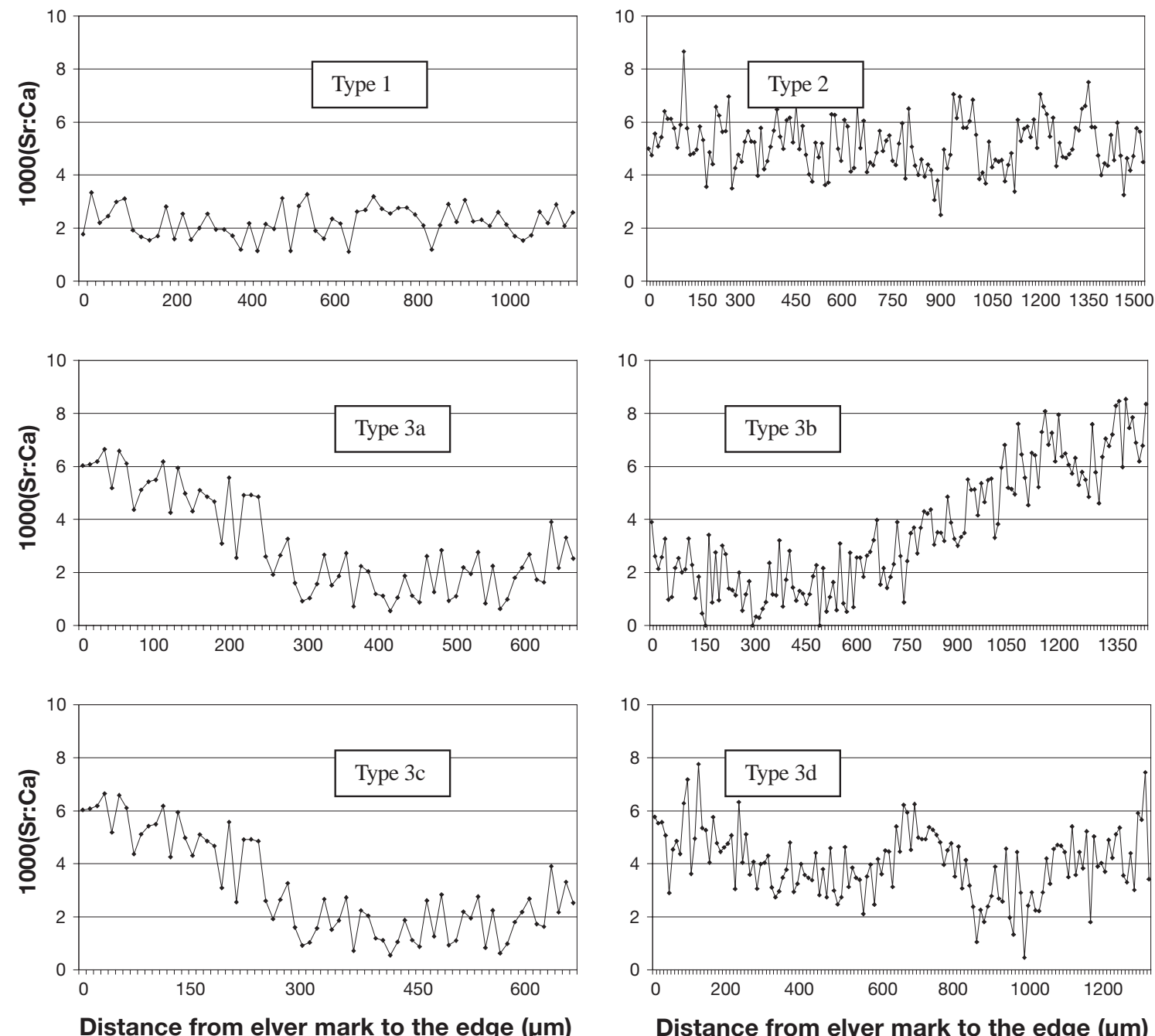

Distance from elver mark to the edge $(\mu \mathrm{m})$

Fig. 4. Anguilla japonica. Sr:Ca ratio variations along transects of Japanese eel otoliths from the first annulus (from glass eel stage) to the otolith edge representative of the main habitat use patterns and collected in the middle and lower reaches of the Kaoping River, SW Taiwan. Type 1: residence in freshwater; Type 2: residence in seawater; Type 3: nomadic movements; 3a: residence in the estuary, movement to freshwater; 3b: residence in freshwater, movement to the estuary; 3c: freshwater residence, movement to estuary then movement to freshwater; 3d: other estuarine behavior with no defined pattern (Tzeng et al. 2002)

\section{Variations in proportions of habitat use patterns}

Freshwater habitats

In rivers, the majority of sampled eels were freshwater residents, with the exception of Anguilla rostrata in the St. Jean River and Sirois Lake (Quebec) (Table 4). The proportion of freshwater resident eels typically increased with the distance to the sea: $A$. rostrata freshwater residents in the Hudson River sampled $190 \mathrm{~km}$ upstream from the river's mouth accounted for $100 \%$ of the sample. The same proportion of freshwater residents $(100 \%)$ was observed for $A$. japonica in the Pearl River and A. anguilla in the Garonne River, in both cases $200 \mathrm{~km}$ upstream from the river mouths. Meanwhile, in the St. Jean River and Sirois Lake, the proportion of eels that were residents in freshwater (23 and $44 \%$ respectively) was lower than the proportion of eels (77 and $56 \%$ ) that undertook movements between habitats of different salinity.

\section{Estuaries and coastal sites}

A considerable fraction of the eels collected in estuaries and coastal sites had experienced freshwater at some point, and in most cases this freshwater episode occurred early in life (Fig. 5). The proportion of fish 
Table 2. Anguilla anguilla, A. japonica and A. rostrata. Diversity of habitat use patterns by species and by site, occurrence in the sample $(+)$, or number of individuals

\begin{tabular}{|c|c|c|c|c|c|c|c|}
\hline \multirow{2}{*}{$\begin{array}{l}\text { Habitat use } \\
\text { patterns }\end{array}$} & \multicolumn{2}{|c|}{ A. anguilla } & \multicolumn{2}{|c|}{ A. japonica } & \multirow[b]{2}{*}{ E Canada ${ }^{\mathrm{e}}$} & \multirow{2}{*}{$\begin{array}{l}\text { - A. rostrata } \\
\text { NE USA }\end{array}$} & \multirow{2}{*}{$\overline{\text { NE Canada }}{ }^{g}$} \\
\hline & SW France & Sweden $^{\mathrm{b}}$ & Taiwan ${ }^{\mathrm{c}}$ & Japan $^{\mathrm{d}}$ & & & \\
\hline \multicolumn{8}{|c|}{ Residence in freshwater } \\
\hline River & 83 & _- & 6 & 6 & 18 & 14 & 36 \\
\hline Estuary & 24 & - & 8 & 2 & 0 & 0 & 11 \\
\hline Sea & 0 & 0 & - & 6 & - & - & - \\
\hline Lake & - & - & - & - & 16 & - & - \\
\hline \multicolumn{8}{|c|}{ Residence in brackish water } \\
\hline River & 2 & - & 0 & + & 32 & 0 & 0 \\
\hline Estuary & 80 & - & 3 & + & 29 & 10 & 2 \\
\hline Sea & 8 & 9 & - & + & - & - & - \\
\hline Lake & - & - & - & - & 0 & - & - \\
\hline \multicolumn{8}{|c|}{ Residence in marine water } \\
\hline River & 0 & _- & 0 & 0 & 0 & 0 & 0 \\
\hline Estuary & 0 & - & 0 & 1 & 0 & 0 & 0 \\
\hline Sea & 26 & 3 & - & 11 & - & - & - \\
\hline Lake & - & - & - & - & 0 & - & - \\
\hline \multicolumn{8}{|c|}{ Nomadic movements } \\
\hline River & 0 & _- & 0 & + & 28 & 0 & 6 \\
\hline Estuary & 69 & - & + & + & 19 & 19 & 65 \\
\hline Sea & 9 & 63 & - & + & 0 & - & - \\
\hline Lake & - & - & - & - & 20 & - & - \\
\hline
\end{tabular}

Table 3. Anguilla spp. Age at habitat change for eels switching habitat once

\begin{tabular}{|c|c|c|}
\hline Life history & $\begin{array}{c}\text { Year of } \\
\text { shift }\end{array}$ & Source \\
\hline $\begin{array}{l}\text { Residence in brackish site, } \\
\text { then shift to freshwater habitat }\end{array}$ & $<6+$ & \multirow{2}{*}{$\begin{array}{l}\text { I. Thibault } \\
\text { et al. (unpubl } \\
\text { data) }\end{array}$} \\
\hline $\begin{array}{l}\text { Residence in freshwater, } \\
\text { then shift to brackish water }\end{array}$ & $<6+$ & \\
\hline $\begin{array}{l}\text { Residence in freshwater, } \\
\text { then shift to brackish water }\end{array}$ & $<5+$ & \multirow[t]{2}{*}{$\begin{array}{l}\text { Tzeng et al. } \\
(2002)\end{array}$} \\
\hline $\begin{array}{l}2 \mathrm{yr} \text { in fresh water, } 1 \mathrm{yr} \text { in brackish } \\
\text { and then residence in freshwater }\end{array}$ & $3+$ & \\
\hline $\begin{array}{l}\text { Residence in freshwater, } \\
\text { then shift to brackish water }\end{array}$ & $<5+$ & $\begin{array}{l}\text { Daverat \& } \\
\text { Tomás (2006) }\end{array}$ \\
\hline $\begin{array}{l}\text { Residence in freshwater, } \\
\text { then shift to brackish water }\end{array}$ & $<5+$ & $\begin{array}{l}\text { Morrison } \\
\text { et al. (2005) }\end{array}$ \\
\hline
\end{tabular}

sampled in the estuary that experienced freshwater at least once accounted for $95 \%$ in the Kaoping estuary, $50 \%$ in the Gironde estuary, $65 \%$ in the Hudson River estuary, $40 \%$ in the St. Jean estuary, and $17 \%$ in the Baltic Sea sample. Residency in estuaries and coastal sites is a less common life history trait than nomadic movements between water masses of different salinity sometimes including freshwater habitats. The proportion of fish that switched habitat at least once varied from $41 \%$ for Anguilla anguilla in the Gironde estuary to $81 \%$ for $A$. japonica in the Koaping estuary. Meanwhile, the proportion of marine and brackish residents in brackish sites varied from $5 \%$ for $A$. japonica in the Koaping estuary to $60 \%$ for A. rostrata in the St. Jean estuary. Considering the silver eel fraction as shown in 2 studies either on A. anguilla (Limburg et al. 2003) or

Table 4. Anguilla anguilla, A. japonica and A. rostrata. Reference and composition of freshwater habitat samples

\begin{tabular}{|c|c|c|c|c|c|}
\hline Species & Location & $\begin{array}{l}\text { Distance from } \\
\text { river mouth (km) }\end{array}$ & $\begin{array}{l}\text { Sample } \\
\text { size }\end{array}$ & $\begin{array}{l}\text { Freshwater } \\
\text { residents (\%) }\end{array}$ & Source \\
\hline A. anguilla & $\begin{array}{l}\text { Garonne River, France } \\
\text { Dordogne River, France }\end{array}$ & $\begin{array}{r}200 \\
80\end{array}$ & $\begin{array}{l}23 \\
40\end{array}$ & $\begin{array}{r}100 \\
95\end{array}$ & Daverat \& Tomás (2006) \\
\hline \multirow[t]{3}{*}{ A. japonica } & Kaoping River, Taiwan & 40 & 6 & 100 & Tzeng et al. (2002) \\
\hline & Pearl River, China & 200 & 74 & 100 & Tzeng et al. (2003) \\
\hline & Fukui River, Japan & - & $\begin{array}{l}2 \\
5\end{array}$ & $\begin{array}{r}100 \\
80\end{array}$ & Tsukkamoto \& Arai (2001) \\
\hline \multirow[t]{2}{*}{ A. rostrata } & Hudson River, United States & 190 & 14 & 100 & \multirow{2}{*}{$\begin{array}{l}\text { Morrison et al. (2003) } \\
\text { I. Thibault et al. (unpubl. data) }\end{array}$} \\
\hline & $\begin{array}{l}\text { St. Jean River, Canada } \\
\text { Sirois Lake, Canada }\end{array}$ & $\begin{array}{r}4.5 \\
80\end{array}$ & $\begin{array}{l}78 \\
36\end{array}$ & $\begin{array}{l}23 \\
44\end{array}$ & \\
\hline
\end{tabular}


A. anguilla

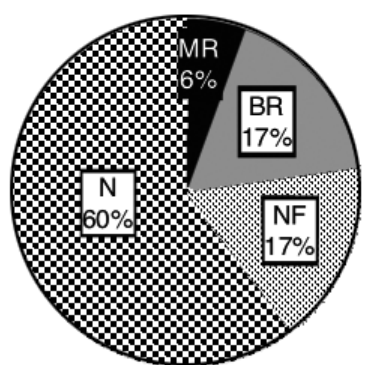

Baltic Sea exit (silver eels)

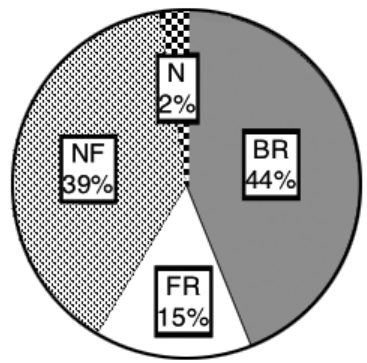

Gironde estuary (yellow eels)

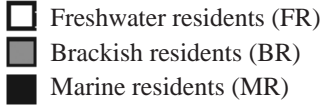

A. japonica

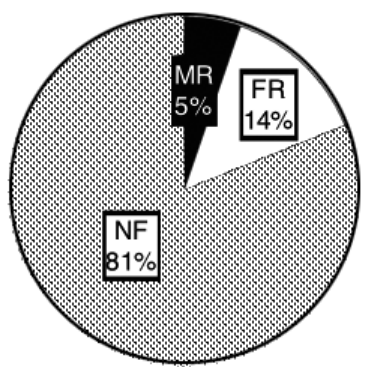

Kaopong estuary (yellow eels)

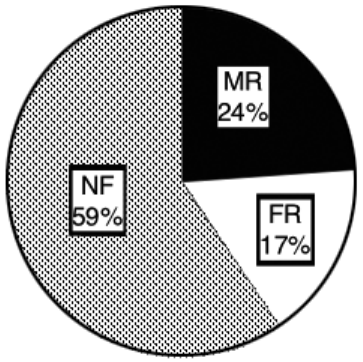

Mikawa Bay (silver eels)
A. rostrata

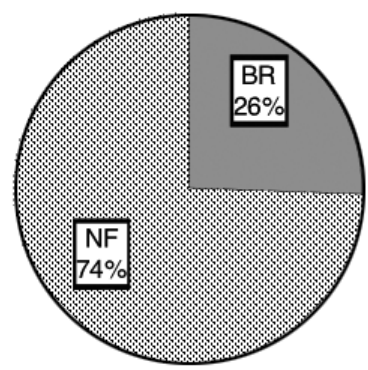

Hudson River estuary (yellow eels)

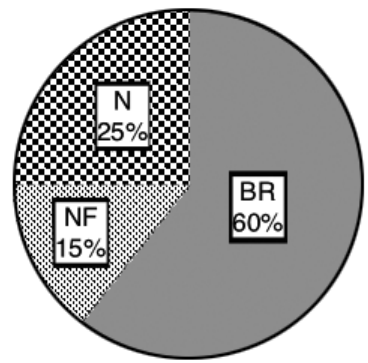

St. Jean estuary (yellow and silver eels)
Eels that enter freshwater as elvers before switching habitat once or several times (NF)
8

All other nomadic eels that stay in brackish or marine environment as elvers and then experience movements between brackish and marine habitats $(\mathrm{N})$

Fig. 5. Anguilla anguilla, A. japonica and A. rostrata. Proportions of habitat use patterns in brackish and marine sites

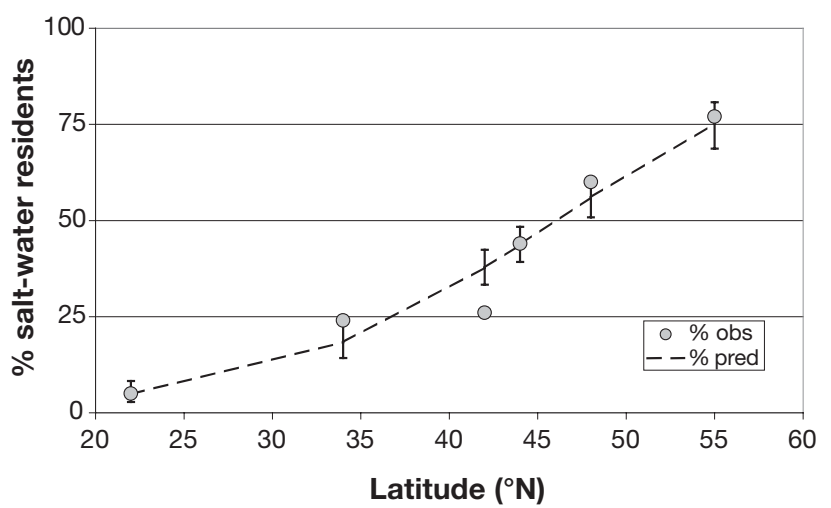

Fig. 6. Anguilla anguilla, A. japonica and A. rostrata. Relation between percentage of salt water residents and latitude in the different estuaries presented in this study (\% observed [obs]), and associated break-point regression fit (model \% predicted [pred]; error bars: $\pm \mathrm{SD}, \mathrm{R}^{2}=0.3$ )

on A. japonica (Tzeng et al. 2003), the samples were mainly composed of 'nomadic' eels. Eels found at higher latitudes exhibited a greater probability of remaining in the lower reaches of watersheds in brackish water (Fig. 6, logit model; $\mathrm{p}<0.0001, \mathrm{R}^{2}=0.3$ )

\section{DISCUSSION}

\section{Diversity and relative proportions of habitat use}

Regardless of species or site, Anguilla anguilla, A. japonica and $A$. rostrata displayed a wide repertoire of habitat use patterns, with up to 6 main types identified for each site as well as a number of less common, intermediate patterns. Moreover, the main patterns of habitat use were the same for the 3 species collected in different sites, with either residence in freshwater/brackish/marine habitat or 'nomadic movement' among habitats. In addition, the patterns of movements found for the 'nomadic eels' were also very consistent. Either a single shift of habitat following a downstream or an upstream movement, or seasonal movements, were found in most of the cases described in our comparisons. Regularity in life history was also observed for eels undertaking a single habitat shift, with the change occurring around age $3+$ for the 3 species. This suggests that an individual eel's ability to change habitat is related to a favourable window for movement, probably driven by size rather than age. The influence of hormones 
on individual migration ability deserves investigation, as growing evidence suggests that glass eels' first habitat selection is partly controlled by thyroid hormones (Edeline et al. 2004). In addition, freshwater habitats might not be very attractive for $3+$ yellow eels as most of our freshwater samples, with the exception of Sirois Lake, do not have 'nomads' that migrate from the estuary to the river. Differences in productivity between freshwater and brackish (estuarine) habitats, and the resulting lower growth of eels in temperate freshwater sites (Helfman et al. 1984, Helfman et al. 1987, Fernandez-Delgado et al. 1989, Lobon-Cervia et al. 1995, Morrison \& Secor 2003), might explain this phenomenon. The similarity of habitat use patterns in A. rostrata, A. anguilla, and $A$. japonica strongly suggests that plasticity in temperate eels is a common life history trait across anguillid species and sites. This observation is also supported by studies on southern temperate eels, such as A. dieffenbachii and A. australis (Arai et al. 2004).

What seems more variable than the diversity of habitat use patterns is their relative proportion among the different species and geographic regions. For example, in the St. Jean estuary $\left(48^{\circ} \mathrm{N}\right), 60 \%$ of the eels sampled in the estuary remained in the estuary compared to $35 \%$ estuarine residency in the Hudson River estuary $\left(42^{\circ} \mathrm{N}\right)$. A predominance of brackish dwelling eels was observed in the Baltic Sea $\left(55\right.$ to $\left.60^{\circ} \mathrm{N}\right)$ while only $44 \%$ of eels were residents in the Gironde estuary $\left(44^{\circ} \mathrm{N}\right)$. In the same manner, in the Koaping River $\left(22^{\circ} \mathrm{N}\right)$, only $5 \%$ of eels were marine residents compared to $24 \%$ in Mikawa Bay, Japan $\left(34^{\circ} \mathrm{N}\right)$. Hence, at the northernmost edge of the species' range, eels tend to be confined in brackish water, as shown by (Arai et al. 2003, Kotake et al. 2004). Natural and artificial obstacles present on the watercourse also constrain habitat use patterns, as in an impounded watercourse in Canada, where Anguilla rostrata displayed only 3 different behaviours (Cairns et al. 2004). This evidence of geographical variability suggests that habitat use pattern expression is determined by environmental conditions.

\section{Strategies of nursery and feeding habitat use}

Regardless of habitat use patterns, all eels share similar marine migrations both from and to their spawning grounds, and display varying levels of catadromy. We emphasize that the plasticity of habitat use patterns at the individual level is a process by which eels occupy their nursery and feeding grounds. Within these areas, the plasticity in habitat use patterns is a strategy that allows eels to colonise a wide variety of ecosystems at the scale of the species' geographical ranges. Unlike other fish species, the niche of eels appears not to be specialised during their growing phase. In accordance with the higher prevalence of anadromy in higher latitudes among salmonids (Gross et al. 1988), eels tend to preferentially occupy brackish and marine habitats at the northern extremes of their distributional ranges for feeding.

\section{Diadromy of eels and colonisation processes}

Although individual authors have reported on the wide variety of habitat uses by individual species, this interspecies comparison demonstrates the breadth of the behavioural repertoire at the genus level, a new insight into eel ecology. It now appears that the genus Anguilla is facultatively (rather than obligate) catadromous, and also, that many individuals captured in estuaries are marine amphidromous (Gross 1988). The combined data sets show a greater proportion of eels that entered freshwater even for a short period of their life span than of eels classified as marine or brackish habitat residents.

Although catadromy is not obligatory, it nevertheless remains a major life history trait for anguillid eels. Compared to marine ecosystems, freshwater stream/river habitats are generally less risky in terms of predation (Jonsson \& Jonsson 1993), and also carry a lower density of eels than brackish sites, as a result of population diffusion processes (Ibbotson et al. 2002). These features permit the survival of a larger diversity of phenotypes and genotypes than in brackish sites characterised by high densities and mortality rates.

The evolution of the high degree of habitat use plasticity documented in this review suggests a remarkable 'bet-hedging' strategy for anguillids as a group. Whether such plasticity represents an ancestral state that is retained among anguillids would require investigation of habitat use patterns of tropical species, hypothesised as ancestral within anguillids. Studies of Anguilla marmorata (Resh et al. 1999) and of A. bicolor bicolor and A. bicolor pacifica (J.-C. Shiao pers. comm.) demonstrated that these tropical eel species can use both freshwater, estuarine and marine habitats.

In conclusion, we have shown that 3 species of anguillid eels display remarkable flexibility in habitat use. These can be classified into several 'eco-types,' whose frequencies appear to vary at least with latitude. More studies of this sort, in more regions, would further elaborate the patterns we have seen. 
Strategic sampling along latitudinal, productivity, or other gradients would allow testing of alternate hypotheses concerning what it is that structures local populations into the different eco-types. Diadromy in eels is more complex than a simple separation into catadromous and non-catadromous individuals. The variants we show, which include marine amphidromy, might be more appropriate to qualify eel life cycles.

Acknowledgements. P. Camoin from Cemagref prepared Fig. 1. We thank J. Tomas for his careful analysis of European eel movements in the Gironde estuary (F.D.). K.E.L. was partially supported by a grant from the National Science Foundation (DEB-0238121). Partial financial support (I.T., J.-C.S., J.J.D., F.C., W.-N.T., Y.I.) comes from the Natural Sciences and Engineering Research Council of Canada (NSERC), Ministère de l'Agriculture, des Pêcheries et de l'Alimentation du Québec (MAPAQ) and Ministère des Ressources Naturelles et de la Faune du Québec (MRNFQ). We thank D. Fournier, V. Cauchon, L.A. Julyan, V. Lavoie, F. Dubé and J.N. Bujold for the eel captures in the St. Jean River watershed (I.T., J.J.D., F.C.). The manuscript was substantially improved by comments from D. Secor, D. Cairns and 2 anonymous reviewers.

\section{LITERATURE CITED}

Arai T, Kotake A, Ohji M, Miller MJ, Tsukamoto K, Miyazaki N (2003) Occurrence of sea eels of Anguilla japonica along the Sanriku Coast of Japan. Ichthyol Res 50:78-81

Arai T, Kotake A, Lokman PM, Miller MJ, Tsukamoto K (2004) Evidence of different habitat use by New Zealand freshwater eels Anguilla australis and A. dieffenbachii, as revealed by otholith microchemistry. Mar Ecol Prog Ser 266:213-225

Bath GE, Thorrold SR, Jones CM, Campana SE, McLaren JW, Lam JWH (2000) Strontium and barium uptake in aragonitic otoliths of marine fish. Geochim Cosmochim Acta 64:1705-1714

Bertin L (1951) Les anguilles. Variation, croissance, euryhalinité, toxicité, hermaphrodisme juvénile et sexualité, migrations, métamorphoses. Payot, Paris

Cairns DK, Shiao JC, Iizuka Y, Tzeng WN, MacPherson CD (2004) Movement patterns of American eels in an impounded watercourse, as indicated by otolith microchemistry. N Am J Fish Manag 24:452-458

Collett D (1991) Modelling binary data. Chapman \& Hall, London

Daverat F, Tomás J (2006) Tactics and demographic attributes of the European eel Anguilla anguilla the Gironde watershed, France. Mar Ecol Prog Ser 307:247-257

Daverat F, Tomas J, Lahaye M, Palmer M, Elie P (2005) Tracking continental habitat shifts of eels using otolith $\mathrm{Sr} / \mathrm{Ca}$ ratios: validation and application to the coastal, estuarine and riverine eels of the Gironde-Garonne-Dordogne watershed. Mar Freshw Res 56:619-627

Edeline E, Dufour S, Briand C, Fatin D, Elie P (2004) Thyroid status related to migratory behavior in Anguilla anguilla glass eels. Mar Ecol Prog Ser 282:261-270

Fernandez-Delgado $\mathrm{CH}$, Hernando JA, Herrera M, Bellido M (1989) Age and growth of yellow eels, Anguilla anguilla, in the estuary of the Guadalquivir river (southwest Spain). J Fish Biol 34:561-570

Fontaine YA (1996) Scénario évolutif pour la mise en place de transitions écologiques: exemple du cycle vital de l'anguille européenne (Anguilla anguilla L.). Bull Soc Zool Fr 12:213-222

Gross MR, Coleman RM, McDowall RM (1988) Aquatic productivity and the evolution of diadromous fish migration. Science 239:1291-1293

Helfman GS, Bozeman EL, Brothers EB (1984) Size, age, and sex of American eels in a Georgia River. Trans Am Fish Soc 113:132-141

Helfman GS, Facey DE, Hales LS (1987) Reproductive ecology of the American eel. Am Fish Soc Symp 1:42-56

Ibbotson A, Smith J, Scarlett P, Aprahamian MW (2002) Colonisation of freshwater habitats by the European eel Anguilla anguilla. Freshw Biol 47:1696-1706

Jessop BM, Shiao JC, lizuka Y, Tzeng WN (2002) Migratory behaviour and habitat use by American eels Anguilla rostrata as revealed by otolith microchemistry. Mar Ecol Prog Ser 233:217-229

Jonsson B, Jonsson N (1993) Partial migration: niche shift versus sexual maturation in fishes. Rev Fish Biol Fish 3: 348-365

Kawakami Y, Mochioka N, Morishita K, Tajima T, Nakagawa H, Toh H, Nakazono A (1998) Factors influencing otolith strontium/calcium ratios in Anguilla japonica elvers. Environ Biol Fishes 52:299-303

Kotake A, Arai T, Ohji M, Yamane S, Miyazaki N, Tsukamoto K (2004) Application of otolith microchemistry to estimate the migratory history of Japanese eel $A n$ guilla japonica on the Sanriku Coast of Japan. J Appl Ichthyol 20:150-153

Kraus RT, Secor DH (2004) Incorporation of strontium into otoliths of an estuarine fish. J Exp Mar Biol Ecol 302:85-106

Limburg KE, Svedang H, Elfman M, Kristiansson P (2003) Do stocked freshwater eels migrate? Evidence from the Baltic suggests 'yes'. In: Dixon DA (ed) Biology, management and protection of catadromous eels. Am Fish Soc Symp 33, p 275-284

Lobon-Cervia J, Utrilla CG, Rincon PA (1995) Variations in the population dynamics of the European eel Anguilla anguilla (L.) along the course of a Cantabrian river. Ecol Freshw Fish 4:17-27

Marui M, Arai T, Miller MJ, Jellyman DJ, Tsukamoto K (2001) Comparison of early life history between New Zealand temperate eels and Pacific tropical eels revealed by otolith microstructure and microchemistry. Mar Ecol Prog Ser 213:273-284

McCullagh P, Nelder JA (1989) Generalized linear models. Chapman \& Hall, London

Morrison WE, Secor DH (2003) Demographic attributes of yellow-phase American eels (Anguilla rostrata) in the Hudson River estuary. Can J Fish Aquat Sci 60:1487-1501

Morrison WE, Secor DH, Piccoli PM (2003) Estuarine habitat use by Hudson river American eels as determined by otolith strontium:calcium ratios. In: Dixon DA (ed) Biology, management and protection of catadromous eels. Am Fish Soc Symp 33, p 87-100

Oberdorff T, Pont D, Hugueny B, Chessel D (2001) A probabilistic model characterizing fish assemblages of French rivers: a framework for environmental assessment. Freshw Biol 46:399-415

Resh VH, Moser M, Poole M (1999) Feeding habits of some freshwater fishes in streams of Moorea, French Polynesia. J Limnol 35:205-210 
Tesch FW (2003) The eel. Blackwell Publishing, Oxford

Tsukamoto K, Arai T (2001) Facultative catadromy of the eel Anguilla japonica between freshwater and seawater habitats. Mar Ecol Prog Ser 220:265-276

Tsukamoto K, Nakai I, Tesch WV (1998) Do all freshwater eels migrate? Nature 396:635

Tzeng WN (1996) Effects of salinity and ontogenetic movements on strontium:calcium ratios in the otoliths of the Japanese eel, Anguilla japonica. J Exp Mar Biol Ecol 199: 111-122

Tzeng WN, Severin KP, Wickstrom H (1997) Use of otolith microchemistry to investigate the environmental history of European eel Anguilla anguilla. Mar Ecol Prog Ser 149: $73-81$

Editorial responsibility: Howard I. Browman (Associate Editor-in-Chief), Storebø, Norway
Tzeng WN, Wang CH, Wickstrom H, Reizenstein M (2000) Occurrence of the semi-catadromous European eel Anguilla anguilla in the Baltic Sea. Mar Biol 137:93-98

Tzeng WN, Shiao JC, Iizuka Y (2002) Use of otolith Sr:Ca ratios to study the riverine migratory behaviors of Japanese eel Anguilla japonica. Mar Ecol Prog Ser 245: $213-221$

Tzeng WN, Iizuka Y, Shiao JC, Yamada Y, Oka H (2003) Identification and growth rates comparison of divergent migratory contingents of Japanese eel (Anguilla japonica). Aquaculture 216:77-86

Van den Thillart GV, Van Ginneken F, Körner R, Heijmans R, Van der Linden R, Gluvers A (2004) Endurance swimming of European eel. J Fish Biol 65:312-318

Submitted: June 29, 2005; Accepted: August 29, 2005

Proofs received from author(s): January 24, 2006 